\title{
Military and Development in Bangladesh
}

\section{Alan Lindquist}

\section{Origins}

The origins of the Bangladesh army lie more than 200 years back in the mercantile period of British expansion when representatives of its commercial capital arrived in India to trade and plunder. The first of the native armed forces commanded by foreigners were the armies organised by governmentsponsored companies, such as the British East India Company. Without these forces, this foreign capital could not have penetrated to the extent that it did, nor have been as financially successful. Thus, even in this early period, the army played an important role in development, albeit the development of Britain and the underdevelopment of India.

When the British government took over direct rule, the East India Company's army became the Indian army. This was ultimately developed into the largest and most effective colonial army in the world. With it, Britain extended its control over India and other areas, suppressed local uprisings, and contained the growing nationalist movement in the 20th century. It was even able to use the Indian army extensively against the challenge of other imperial powers in World Wars I and II. The British governing class, with the confidence and skill developed over centuries, accomplished this difficult task only through careful recruitment, training and organisation of Indian soldiers.

At the beginning, recruitment naturally came from the areas first conquered by Britain: Bombay, Madras, and especially Bengal. But after the entire Bengal army revolted against the British in the famous Mutiny of 1857 , the 82 Bengal regiments were disbanded and further recruitment from this area was banned until 1910. Subsequently, the British developed the myth of the martial races which survives to this day in India and Pakistan, if in a somewhat attenuated form. According to this myth, there existed in India certain ethnic, regional or caste groups that were vigorous, courageous and warlike, and which ought to be recruited into the army. Most recruitment for Britain's Indian army after 1857 was done in India's north-west regions, from the Punjabis, Dogras, Jats and the Gurkhas from Nepal. The British protected these groups and encouraged them to regard themselves as superior. It is significant that education and political consciousness tended to be less widespread in these areas than in Bengal or Madras.
On the other hand, there were other 'races' who did not possess the required martial spirit. The Bengalis were decidedly placed in the latter category. The contempt for the Bengali population shown by the Pakistan army at the time of the crackdown in 1971 can in part be traced to these theories of racial superiority.

The Indian army was effectively insulated from the growing nationalist movement in the 1920s and 1930s against which it was often used, although during World War II this insulation began to break down. With the partition of British India into independent India and Pakistan virtually all the Muslim officers and soldiers trained by Britain joined the armed forces of the Islamic State of Pakistan. These two vivisected halves of the original Indian army fought their first skirmishes in 1948 over the control of Kashmir.

\section{Post-Independence: the Pakistan army}

This conservative and 'anti-national' military establishment inherited from the Empire became the armed protector of the post-colonial State. The experience of the nationalist struggle left a good deal of resentment against military institutions. But in Pakistan there was almost no thought of tampering with the traditional military structure.

Pakistan was officially an Islamic State and its rulers had little of the socialist, secular, and 'non-aligned' character of the Congress Party government in India. The US began providing it with military and economic assistance in 1951, and when Pakistan joined Dulles' two anti-Communist alliances, SEATO and CENTO, that aid increased. By 1969 Pakistan had received up to $\$ 2,000 \mathrm{mn}$. in American military assistance and $\$ 3,000 \mathrm{mn}$. in economic aid. A large US military mission trained, equipped, and advised the armed forces. The army expanded rapidly, more than tripling its manpower between 1947 and 1971, and acquired sophisticated weaponry from the United States. A US government report stated in 1962: "From a political viewpoint, US military aid has strengthened Pakistan's armed services, the greatest stabilizing force in the country ..." (quoted in Feroze Ahmed 1962: 429).

US military assistance converted the Pakistan army into the dominant political force and chief defender of the propertied classes in the country. The increased strength and confidence of the army was demonstrated in its seizure of power in the 1958 coup 
d'etat. The coup was led by Sandhurst-trained General Ayub Khan, who later admitted consulting US officials, including the director of the CIA, Allen Dulles, before taking power.

Army rule only exacerbated the conflict between East and West Pakistan. It prevented the former from using its larger population in parliamentary elections to obtain policies favourable to its own interests. It also meant greater economic exploitation of the East. The military consumed as much as 60 per cent of Pakistan's budget. Foreign exchange derived mainly from jute exports from the East was drawn upon to purchase foreign weapons especially after the 1965 war with India when most US military assistance was cut off. Yet most military troop deployment was in the West and the East gained little from military spending and the jobs it created.

The Pakistan army continued the British pattern of recruiting mainly among the 'martial races' of the Punjab and Northwest Frontier Province. Bengalis made up less than 10 per cent of an army estimated in 1971 at 350,000 although they constituted 56 per cent of the national population. And only two out of the top 50 officers in post-Independence Pakistan were Bengalis.

The growing economic disparity between East and West, the former's lack of a voice in its own affairs, the geographical absurdity of the country to begin with, and the great cultural differences between the two regions combined to produce an increasingly potent nationalist brew in the East. Accumulated grievances burst forth in large-scale student and workers riots during 1968-69, leading to the fall of the Ayub regime. A new military administration calling itself an interim government promised nation wide elections. These were held in December 1970 and fought on the issue of provincial autonomy. The Awami League led by Sheikh Mujibur Rahman won an overwhelming victory in East Bengal with a large enough majority to dominate the new National Assembly and make Mujib the next Prime Minister of Pakistan. West Pakistani interests saw their domination threatened, and the military regime of Yahya Khan postponed the convening of the Assembly. The Awami League responded by organising a mass campaign of unarmed resistance. The West Pakistani military rulers answered this political challenge with one of the most brutal military onslaughts seen in South Asia.

\section{War of Independence}

When the Pakistan army began its crackdown on the night of March 25,1971, the first objective was to disarm the Bengaliunits of the armed forces. ${ }^{1}$ But this proved to be more difficult than expected and resulted in their revolt and armed resistance. Bengali units in the armed forces had been moved by the nationalist sentiment that swept the eastern wing of Pakistan. These regular forces in the army and police formed the initial core of the resistance, but had no training or experience in guerrilla warfare. They did not yet know how to mobilise the overwhelming support of the Bengali population and offset the greater number of trained West Pakistani soldiers and their superior firepower. In the two or three weeks after the Pakistani crackdown began Bengali troops tried to engage them in different parts of the country by conventional tactics. These 'set-piece' battles proved to be costly mistakes, resulting in the defeat of all organised Bengali resistance by the end of April 1971. The remnants of the Bengali units crossed the border into India with their officers.

The second phase of resistance to Pakistani repression took three main forms. The first, which may be termed the 'official' resistance, came directly out of the post-colonial army tradition. It was made up of the regular Bengali units guided by a conventional approach to military matters. This group is best represented by Majors Safiullah and Khaled Musharraf, who became top-level sector commanders, and above all by Colonel M. A. G. Osmany, a retired East Pakistani military officer who was appointed Commander of the resistance forces by the Awami League government in exile. Their approach was to organise all the trained Bengali military personnel into conventional units which would operate from bases in India. And their political goal was to bring an Awami League government to power in Bangladesh as soon as possible by whatever means including direct Indian intervention.

The Indian government had decided by the middle of April 1971, that it was in its own national interest to aid the resistance in East Pakistan. India had fought two inconclusive wars with Pakistan since Independence and saw this as the opportunity of the century to cut its enemy to size and assert itself as the dominant power in the region. The Indian Congress Party government also desired to bring to power an

\footnotetext{
1 The Bengali armed forces in East Pakistan at the time were six battallions of the East Bengal Regiment (EBR), numbering about 6,000 men, plus 13-14,000 lightly-armed troops of the border security force, the East Pakistan Rifles (EPR). In addition there were some 45,000 police in the province, not all armed, who mostly went over to the resistance, as well as others in home-guard type militias. General Osmany, the retired East Pakistani army officer who took command of the Bangladesh liberation forces during the war was later to say that the 'Bengali personnel in the army might well have stayed neutral, had the Pakistani authorities confined their crackdown to selected Bengali politicians. It was the over-kill, the systematic 'elitocide' campaign to exterminate professionals, intellectuals and army officers that decided them to revolt.' (Palit p. 54).
} 
Awami League government in Bangladesh which was similar in character to itself in its policies of secularism and in its international alliances.

A second strategy centred around a number of experienced officers who largely rejected the strategic concepts being advanced by General Osmany and Indian field commanders. This dissident group was led by Majors Taher and Ziauddin who had both been stationed in West Pakistan when the crackdown began, but escaped and joined the Bangladesh resistance. As sector commanders of the Mukti Bahini, they rejected the Bangladesh Command's view that all sectors should establish their command headquarters on Indian territory, and insisted to the contrary that both the political capital and all military headquarters should be based on Bangladesh soil.

They also argued against the formation of conventional battalions. Instead they wanted all experienced military personnel dispersed in the districts of the country with orders to raise and train peasant guerrilla battalions. Within a year Taher estimated that a peasant army of more than 100,000 men could be raised. Emphasis was put on capturing enemy equipment rather than relying on foreign supplies. It was only through a 'people's war' that the technical superiority of the Pakistani forces could be defeated without foreign intervention. This was in their view the only way Bangladeshis would win independence for themselves without Indian military intervention to which they remained categorically opposed.

The third form of resistance was the action by civilians who armed themselves in all parts of Bangladesh. Such groups ranged from those activated by Marxist parties such as the East Bengal Communist Party led by Abdul Matin to the private forces of semi-bandit elements such as Kader Siddiqui. But most groups arose without prior organisational form and were led by the new young patriots of the Bangladesh movement. It was with these elements that military officers like Taher and Ziauddin hoped to merge their trained personnel and thus build an army of a type never seen before in South Asia.

So we have seen the factors that inhibited the development of a people's army and people's war: the core of the resistance was the Bengali elements of the Pakistan neo-colonial army with conventional ideas of military strategy and acceptance of the limited petty bourgeois nationalist political goals of the Awami League. Indian tutelege reinforced these tendencies. Another important factor was the division of the left forces, especially the pro-Chinese parties, and confusion over the national question when China supported the unity of the Pakistan state. Nevertheless, the struggle in Bangladesh began to move leftward. A split developed and widened, between the Awami League politicians, who for the most part were safely ensconced in the exile government in 'Mujibnagar' (Calcutta), and the military units fighting in the field. Yet in the final analysis the Bangladesh resistance did not become a people's war of national liberation because it did not have time to develop before India stepped in.

Once war was declared on December 3, 1971, India moved swiftly into East Pakistan with approximately 150,000 troops-roughly twice as many as Pakistan had there. In a well-planned and executed operation the Indian army defeated, skirted, or set to flight the major Pakistan troop concentrations and surrounded the capital, Dacca, in just two weeks. The lack of fight in the Pakistan troops, commented on by a number of observers, seems to have been largely due to their feeling of isolation among a hostile population. The Indian army commanders accepted the surrender of the Pakistan army on December 16 with no representative of the Bangladesh government-in-exile nor the Mukti Bahini even participating in the ceremony. The Pakistani prisoners of war and most of their weapons and equipment were quickly taken off to camps in India. ${ }^{2}$ These and other actions caused considerable resentment among the Bangladesh forces.

Pakistan was persuaded by Western governments to release Sheikh Mujibur Rahman from prison in early January, 1972, and he returned to a tumultuous welcome in Dacca. One of the first tasks he set himself was the disarming and disbanding of the groups of freedon fighters, and the organising of his army and 'security forces'. Indian and Awami League planners had given thought to the situation after Bangladesh had achieved its independence. The Indian General D. K. Palit somewhat coyly reveals that:

"(by October, 1971) some of former regular personnel of the EBR were grouped into regular units or sub-units in order to enable them to operate alongside Indian army troops should the need arise, particularly in the eastern sector. Besides, the leaders of the Mukti Bahini must have realised that when Bangladesh was eventually liberated, the administration would feel the need for a cadre of regular troops-for internal security roles to begin with-and subsequently, to form the nucleus of a Bangladesh army" (emphasis added) (Palit, p.58).

\footnotetext{
2 Some four divisions worth of weapons and equipment were taken away by the Indian army and never recovered by Bangladesh, though in 1973, due to Bangladesh army protests, India did give them some old World War II artillery pieces.
} 
A Bangladesh army of 10,000 men initially was formed on the lines of the Indian and Pakistan armies with considerable Indian assistance. The traditional, hierarchical structure with a professional officer corps was re-asserted. Mujib promoted General Osmany and moved him into his cabinet, but refused to give him the Defence post for fear he would have too much influence. The relatively pliant Safiullah was promoted to command of the Bangladesh army over the head of Ziaur Rahman, a hero of the resistance who had actually declared the independence of Bangladesh over Chittagong Radio on March 26, the morning after the crack-down began. Ziaur Rahman got the number two post, and Mujib put the highly ambitious Khaled Musharraf in as number three. Safiullah and Khaled, as was mentioned above, were leading members of the first, 'official' stream of the resistance movement with its conventional military approach and willingness to depend on India for major assistance in winning Bangladesh independence. Ziaur Rahman, however, held something of an intermediate position between the first and the second approaches. Although he does not seem to have thought in terms of a socialist future for Bangladesh, he was a nationalist who did not want the country's independence to depend on India and therefore had supported Taher in operating his military command as much as possible from within Bangladesh.

Those soldiers who wanted a new form of army were over-ruled and if they persisted, expelled. A number of outstanding young officers whose ideas had been transformed by the experience of fighting in the national liberation struggle were forced out. One of these was Major M. A. Jalil, a Bengali officer who had been on leave from his Pakistan regiment at the time of the crack-down and had organised resistance in his home area of Barisal. He then became the commander for the ninth sector (Jessore-Khulna). Immediately after the war he was arrested and imprisoned for several months for trying to prevent Indian troops from taking industrial machinery and military weapons and equipment away to India. Expelled from the army on his release, he helped to found a new party, the JSD (Jatiyo Samajtantric Dal, or 'patriotic socialist party'), which has been one of the most active left-wing parties since. Except for a two-week period after the soldiers' uprising of November 1975, he has been in prison since 1974 .

Two other examples are Lt. Colonels Ziauddin and Abu Taher, mentioned above and both leading advocates of the 'second stream' strategy of not depending on India for support. After the war Ziauddin was appointed commander of the Dacca Brigade - the most important in the country. But six months later he was sacked from his command and expelled from the army. Ziauddin had publicly called for the abrogation of the government's alleged 'secret treaties' believed to have been made with India during the exile period, and had maintained that the army ought to carry on to build a new socialist Bangladesh, without Mujib if necessary. He also opposed Mujib's creation of a parallel political army: the Rakkhi Bakini. After his expulsion, Ziauddin spent months travelling to all parts of Bangladesh, and in extensive studying of Marxist works. He then went underground to organise and fight with one of the marxist revolutionary parties, the Sarbohara ('have-not's') party led by Siraj Sikdar.

Lt. Colonel Taher, who had commanded the Mymensingh sector in the liberation struggle and had lost a leg leading an assault on a Pakistani position, was after Independence first appointed Adjutant General of the army, in which position he brought proceedings against high officers, including Safiullah, for misappropriation of property. Then he became commander of the Comilla brigade. Taher forcefully advanced the position that the post-independence Bangladesh army should be a 'people's army' that would engage in construction and productive tasks so as not to be a burden on the peasantry and had put these concepts to work in his brigade. For this, he and other like-minded officers became known within the army as the 'plough soldiers'. Taher supported Colonel Ziauddin in his clash with Mujib, and as a result left the army but was given the direction of a government dredging operation. In 1974 after most radical left parties had been forced underground, Taher began organising the secret Biplobi Sainik Sangstha ('revolutionary soldiers' organisation') within the army, which had links with the JSD party. This soldiers' organisation was to play an important role in the soldiers' uprising of November 1975.

Besides the army, a new type of explicitly political armed force was also organised in Bangladesh with Indian assistance: the Jatiyo Rakkhi Bahini (JRB) or 'national security force'. Similar to the Indian Central Reserve Police, the JRB was meant as both a counter-weight to the army, which Mujib did not fully trust, and as an 'internal security' instrument to carry out operations of a political nature which it was felt the police were incapable of handling. The Rakkhi Bahini was frequently used to suppress opposition political rallies and demonstrations, control worker's strikes, pick up and interrogate leftists, clear slum dwellers out of the capital, and so forth.

The Rakkhi Bahini was trained by Indian army officers in Bangladesh, but later, because of antiIndian sentiment, JRB officer candidates-who often had Awami League party connections-were sint to be trained at India's military academy at Dehra Dun. 
The Rakkhi Bahini was organised along army lines, but did not possess tanks, artillery, or planes. It did have the latest small arms, however, like Russian AK-47 automatics while the army was left with World War II rifles. Large sums were expended on it and it was built up to a size which rivalled the army: more than 20,000 men by the end of 1974 .

The formation of the Rakkhi Bahini caused considerable resentment in the regular army. In addition, the army had other grievances. For one thing, it was Sheikh Mujib's political style to encourage factions which he could play off against each other, including in the military. The army also resented the way it was used in civil operations. Mujib had ordered the army out on April 24, 1974, to conduct an all-out operation throughout the country to recover unauthorised weapons, stop smuggling, apprehend anti-social elements, and prevent hoarding and profiteering of food grains. Some of the people arrested for smuggling foodgrains, however, turned out to have important Awami League connections, and the army was soon called off this operation. These grievances surfaced in the army coup of August 15, 1975 which killed Mujib and most of his family and overthrew his government.

\section{The domestic context of the coup}

Often in military coups, the internal grievances of the army are only the epiphenomena of important underlying social dynamics. Thus it is necessary to specify the international as well as the internal context of the coup in its social, political and economic dimensions, and identify the forces operating through the military.

Bangladesh is perhaps unique for having in effect deported its 'feudal' landed class-which was mostly Hindu-to India in 1947, and then for having deported its bourgeoisie-mostly from West Pakistan -to Pakistan at Independence in 1971. The 'leading' (but not actually 'dominant') classes that remained can be roughly termed petit-bourgeois, and nearly all of them were represented in the Awami League. These included: traders and merchants of all sizes, the bureaucracy, military officers, professionals, contractors and rich peasants. There was also a small productive bourgeoisie that Ayub Khan had begun to foster as part of state policy in the 1960s. There were certainly many common aspects in the interests and outlook of these groups but they were by no means identical. Once Independence was gained and the Awami League took power, the divergence in their interests increased. The interests of the Awami League Party were not the same as any one class, nor as a party were they necessarily the same as the coalition of interests the party contained.
When the Awami League took power after Independence it began to take on some of the aspects of a class itself. The larger economic interests belonging to West Pakistanis were nationalised, and put under the direction of people with close Awami League connections. The party was in this respect setting itself up as a bureaucratic bourgeoisie. Smaller enterprises often went directly to party members. The government also distributed licences and import and export permits to party members who re-sold them to genuine producers and traders. A lucrative smuggling operation developed which took rice and jute to India, and brought back manufactured goods, an operation which depended on the protection of important people in the party. And finally, full use was made of the opportunities to extract percentages for the award of contracts.

Most important of all, however, was the control over huge amounts of foreign aid that came flooding into the country. Over $\$ 2.5$ billion in aid was received by Bangladesh in the first three years of independence, which is more than the total amount received by East Pakistan in the previous 23 years, and more in absolute dollar terms, than went to West Germany under the Marshall Plan after World War II. A substantial amount of this aid is believed however to never have reached its intended recipients.

The situation described here reflects the petit bourgeois class base of the Awami League in a situation where it suddenly assumed control of the government and acquired opportunities to appropriate surpluses by means which were previously beyond its grasp. If the League had represented a developed bourgeoisie things probably would have been different. At least there would have been an emphasis on production. Splits in the ruling party which manifested themselves at the time of the 1975 coup when some sections of the party supported the elimination of Mujib, suggest that a conflict was developing between the petit bourgeois and the nascent bourgeois elements with roots in production rather than trade or the plunder of state resources. The army, bureaucracy, and international capital seem to have swung behind the latter.

Mujib also alienated the bureaucracy, which was not accustomed to operating under the direction of a political party at all. Mujib intervened in; its operations in a blatantly political way. He promoted his brother-in-law from a junior position in the civil service to be the Joint Secretary of the Establishment Division-a key post which controlled all recruitment, assignments and promotions in the civil service. He also pushed through legislation which allowed summary dismissal of any civil servant without any possibility of review by the judiciary. Most threatening of all, however, was a planned major administrative reorganisation which was about 
to be implemented when Mujib was overthrown. This would have turned all 62 Sub-divisions of Bangladesh into Districts, with local political councils in charge of each, considerably undercutting the power of the Civil Service.

There were also important developments in the economy which had been severely disrupted by the war of independence. Millions of people had fled to India, communications were destroyed, and industrial installations damaged. This led to decline in exports of jute and tea, the main earners of foreign exchange. Thousands of trained Pakistani managers and technicians left the country. These problems were exacerbated by poor rice harvests. As a result agricultural and industrial production had not fully recovered pre-war levels by the time of the 1975 coup. During the same period the population increased by about 12 per cent, resulting in a substantial drop in net per capita domestic product. These factors, combined with a substantial increase in the money supply and a drastic increase in prices for necessary imports including oil, food and cement, produced inflation ranging between 40 and 100 per cent per year.

Corruption and failure to solve the economic problems of the country eroded the Awami League government's support and fostered militant opposition, especially from the JSD party. Mujib's response was increasingly authoritarian-to move in the direction of a one-party State and to rely more and more heavily on the Rakkhi Bahini. In December 1974 a state of emergency was declared. The following month the formation of a single national party (BKSAL, "Bangladesh Peasants and Workers People's League") with compulsory membership for all civil servants, teachers, and journalists was announced. The parliamentary system of government was scrapped in favour of a presidential one. In March Mujib announced his 'Second Revolution' which included a major administrative re-organisation, compulsory cooperative societies in each village, and the formation of special 'judicial tribunals'. In April, all 100 Taka currency notes were suddenly taken out of circulation in a move aimed at smuggling and undeclared earnings, though it also appears to have hit legitimate trade and business badly. And in June, the government announced it was cutting down the number of daily newspapers to two--one in English and one in Bengali-under direct government control.

\section{The international dimension}

There are two main levels at which international forces can operate to produce a military coup in a developing country. The first is by more or less direct intervention by a developed country through an agency such as the CIA. Imperialist forces have shown themselves quite capable, through networks developed over decades in the military and intelligence establishments, of precipitating a coup. Secondly, in a more subtle and sometimes not fully intended manner, the developed countries set the general economic conditions within which developing countries must operate. Sometimes international creditors put them in a situation where it is virtually impossible both to meet external financial demands, and to maintain a democratic political system at home. This conflict seems increasingly to be resolved to the detriment of democracy.

To consider the latter aspect first, international economic forces entirely outside the control of the Bangladesh government played an important role in the inflation and shortages within the Bangladesh economy. In retrospect, these forces and the dislocation caused by the war probably had more effect than smuggling, corruption, and government inefficiency. ${ }^{3}$ Bad harvests in many parts of the world drove up food prices, the price of rice on the international market rising more than five-fold between 1970/71 and 1974/75. And after the Arab oil boycott of late 1973, petroleum, of which Bangladesh imports all its requirements, quadrupled in price.

At the same time, foreign aid, which had flooded into the country after the 1971 war, began to fall off. It was clear to the Bangladesh government by early 1974 that foreign food aid would still not cover expected food deficits for that year. Consequently, it made arrangements to purchase food grains from the US. But with the rapid rise in international food prices and a drastic fall in its own foreign currency reserves it found it could not purchase that food without special credit which the US refused to provide because Bangladesh was selling jute to Cuba. No new food sales agreement was signed until October 1974, after the last jute shipment had left for Cuba. By the time the food reached Bangladesh, the famine had run its course, leaving somewhere between 25,000 and 500,000 people dead, depending on whose estimate one believes. International economic forces as embodied in the IMF and the World Bank also forced Bangladesh to devalue its currency by 37 per cent in April 1975, worsening the rampant domestic inflation.

As for more direct involvement by foreign governments in the 1975 coups, there is no hard evidence, although rumours persist of American involvement in the first. Some observers have noted that the three civilians with apparent prior knowledge of the August 15 coup against Mujib who took part

\footnotetext{
3 It must immediately be said, however, that the Awami League government. of Sheikh Mujibar Rahman totally failed to set an example of sacrifice and national service or to nobilise the population for reconstruction and development.
} 
in the post-coup government all had American connections: Mushtaque Ahmed, Taheruddin Thakur, and Mahabubul Alam 'Chashi' had been together in the Awami League government in exile in Calcutta, 1971. And all three had participated in an abortive secret Kissinger initiative to try to reach a compromise with Pakistan. But the evidence connecting the Americans with the coup remains only circumstantial.

\section{The first coup: August 1975}

The key plotters were six young Majors and exMajors of the Bangladesh army and a retired army intelligence Colonel. The brains of the operation seems to have been Khandaker Abdur Rashid, Commander of the artillery unit in the capital, although he has avoided public statements about his role. Others in the planning group were Rashid's brother-in-law, Farooq Rahman, who commanded the Bengal Lancers tank unit, and two ex-Majors who had been cashiered from the army because of their conflicts with important Awami Leaguers: Shariful Huq Dalim and Shamsul Islam Noor. There was little ideology behind their coup beyond 'down with the tyrant' sentiment. Planning for the coup probably began several months before and by the time it took place some 20-30 additional officers had been brought into the conspiracy. The main force of the coup was the tank regiment with its Russian T-54 tanks commanded by Major Farooq Rahman.

Moving out of the military cantonment area early on the morning of August 15, this force assassinated Mujib and a number of his relatives and very quickly overcame all organised resistance.

The two Awami League politicians mentioned above possibly participated in the planning of the coup. Khandaker Mushtaque Ahmed, a conservative and relatively anti-Indian and pro-American, was appointed President. A civilian cabinet was sworn in, which included many of Mujib's former ministers. Some of the more corrupt or more pro-Indian former Awami League politicians were arrested. The Majors who carried out the coup showed themselves to have no real plan for the country, nor did they have strong backing in the army beyond their own tank and artillery regiments and a limited number of support troops. They did not attempt to assume full command of the army or to displace the more senior officers. An unstable situation developed, with the Majors living in the presidential palace with President Mushtaque Ahmed, protected by their tanks.

The second coup and the soldiers' mutiny: November 1975

On November 3, 1975 twelve weeks after the first coup, a second coup occurred led by Brigadier Khaled
Musharraf - the army second in command. This coup appears in part to have been a reassertion of the hierarchy of command in the army against the power wielded by the Majors. Khaled Musharraf was also considered to be pro-Indian, and rumours circulated that he had acted in coordination with the Indian ambassador, Samar Sen. According to these rumours, Musharraf planned to release Tajuddin Ahmed and other pro-Indian ex-ministers from prison and establish a government which would invoke the India-Bangladesh security treaty of 1972 in order to obtain the support of Indian troops. Before he could release them, however, Tajuddin Ahmed and three other former ministers were murdered in prison. Apart from this, the second coup was pulled off successfully. Musharraf placed the only officer senior to him, General Ziaur Rahman, under arrest and he allowed the Majors and other officers associated with the August coup to leave the country.

After this however the situation quickly began to disintegrate. Khaled Musharraf was widely regarded as 'India's man', and this aroused intense opposition within the army. This sentiment was combined with a smouldering class-resentment in the ranks. It was at this point that the Biplobi Gono Bahini (People's Revolutionary Army-PRA)-the underground armed wing of the JSD party-and the Biplobi Sainik Sangstha (the Revolutionary Soldiers Organisation) that the JSD and Abu Taher had been organising within the army, emerged on the scene. PRA organisers distributed thousands of leaflets throughout the country's military cantonments on November 5 and 6 claiming that the army officers were exploiting the Jawans (soldiers) for their "own selfish and ambitious scrambles for power through staging one putsch after another". (FEER, December 5,1975 ) and calling on the Jawans to rise up against the upper echelons of the officer corps.

This appeal struck a responsive chord. On the night of November 6 , the soldiers began to rise, with a force that was to shake the State in Bangladesh, in the first soldiers' mutiny on such a scale since the Sepoy Mutiny of 1857. Most of the troops of the 46th Infantry Brigade in the Dacca Cantonment joined the rebellion and began firing at Khalid supporters, suspected Indian agents and collaborators, and those considered 'corrupt'. General Khaled Musharraf and a few other associates were assassinated. And a squad of troops led by Colonel Abu Taher, organiser of the PRA, freed General Ziaur Rahman and asked him to speak to a gathering of revolutionary soldiers, which he refused. He was also presented with a list of 12 demands by the soldiers. The first of these stated that :

"This time we revolted not for the cause of the rich and also not on behalf of them. We revolted this 
time along with the masses of the country. From today onwards the armed forces of the country will build themselves as the protectors of the interest of the country's poorer class" . . (FEER, December $5,1975)$.

The others ranged from the immediate release "of all political prisoners" to the demand that "all properties of corrupt elements should be seized, and arrangements should be made to bring back the money from foreign banks of corrupt persons who deposited there earlier.". .

The soldiers also called for a new structure of authority and decision-making in the army, including the end of discrimination between officers and soldiers; an end to recruitment of officers from the privileged classes and through special schools, rather from "among the soldiers" and changing of existing "British military rules and regulations". A number of demands were made for improved wages for soldiers and free accommodation. Soldiers also demanded the abolition of the 'batman' system where rank and file Jawans were used as house and personal servants by higher officers.

Although General Ziaur Rahman, in the pressure of the moment, indicated his general agreement with these demands, they obviously were not consistent with the type of army he envisioned.

Troops from outlying areas poured into Dacca on the morning of November 7 and paraded through the city streets shouting slogans and firing their weapons into the air. There were two different political strands involved, some shouting in favour of the "unity of revolutionary soldiers, workers, peasants and students' and others in support of Allah, Mushtaque, and against India (FEER, December 5, 1975). Officers and their families began fleeing the Dacca cantonment area, there were reports of soldiers ripping off the badges of rank from officers' uniforms and a number of officers and soldiers were killed.

Under pressure from Taher and the revolutionary soldiers, General Zia released JSD leaders A. S. M. Abdur Rab and (ex-Major) M. A. Jalil. Upon their release, however, $\mathrm{Rab}$ and Jalil called for the extension of the rebellion, and urged the formation of 'revolutionary councils' among soldiers, workers, peasants and intellectuals to help make the proletarian revolution. General Ziaur Rahman was meanwhile moving in the opposite direction, and attempting to restore 'order' and the hierarchy of command. He broadcast appeals to "all brothers in the army" to remain at their posts and to remind the population of the ban on public meetings, demonstrations, and strikes.

Seeing the direction of events, Colonel Taher, Abdur Rab, M. A. Jalil and other JSD leaders went underground, but most of them were arrested late in November and charged with 'sedition and rebellion', under an old British colonial statute, along with $\mathbf{3 0}$ others, including 22 members of the armed forces. They were tried several months later before a secret military tribunal. In July 1976 Taher was sentenced to death, Rab and Jalil got life imprisonment, and there were heavy prison sentences for most of the rest.

Thus the rebellion was crushed. An important element in its failure was the lack of an organised mass movement outside the army to link up with. And yet the situation within the army is not the same as it was before. After two coups and a number of attempted coups, a major soldiers' mutiny and several more minor ones and numerous acts of 'indiscipline' in the ranks, the unity of the armed forces is demonstrably weak. And yet most observers agree that the military in Bangladesh is the last institution holding the traditional class and governing structures together.

The military and internal security forces in Bangladesh have been considerably strengthened since the army came to power. The command structure carried out a major re-organisation and redeployment of the army in March-April, 1976 to break up concentrations of potentially dissident troops. A new Division was created to take charge of security in the capital. According to reports circulated by the JSD party, some 1,500 soldiers and officers have been dismissed or tried for sympathy with the Revolutionary Soldier's Organisation.

The budget allocation for defence and internal security forces has been increased two-and-a-half times, to Ta. $2194 \mathrm{mn}$, (about $£ 80 \mathrm{mn}$ ) for $1976 / 77-$ around 30 per cent of the total budget. Police forces have been increased from 40,000 to 70,000 , including a new combat-ready Special Police Force of 12,500 . This essentially replaces Mujib's Rakkhi Bahini, which was disbanded after the first coup.

Bangladesh has received substantial foreign assistance in this build up of 'security forces'. In January 1977 for example the arrival of a squadron of US Bell 212 military helicopters of the type used in Vietnam was announced. These are evidently intended for use by the tactical/mobile Special Police Force. Britain, as part of its 'development' assistance programme, has provided a grant of $£ 720,000$ for a police telecommunications system to link up outlying police stations. The US government has also quietly sold $\$ 1.5 \mathrm{mn}$. worth of telecommunications equipment to the Bangladesh police and has requested a $\$ 200,000$ appropriation from Congress for fiscal year 1978 to train Bangladesh military officers in the US. 
There are many ironies in the way the situation has developed since the coup. Ziaur Rahman had supported Taher in many of the positions he put forward on military matters in the liberation struggle and afterwards. They had been "close comrades in arms'. And Taher and Ziauddin had helped build up the reputation of Ziaur Rahman within the ranks of the army as an honest nationalist officer. It is tragic for the revolutionary soldiers that the General they freed and re-installed as commander of the armed forces should be the one to crush the soldier's movement and execute Taher! And how ironic that this General, who had been a nationalist and leading patriot of the Bangladesh independence struggle should come to head a regime which increasingly depends internally on Bengali elements which did not participate in the independence movement such as the Muslim right, and the "returnees" in the bureaucracy and the army (who now make up 50 per cent of the troops and 70 per cent of the officers); and internationally on the nations which actively opposed Bangladesh independence, the US, China, and Pakistan.

When the soldiers rose in 1975 , the history of Bangladesh had reached a critical turning point at which it was necessary either to go forward with the revolutionary soldiers toward a new revolutionary socialist army and society, or to retreat and make alliance with conservative forces to try to preserve the traditional military and social structures. Perhaps it is not surprising that General Ziaur Rahman chose the latter course-few senior military officers trained in the traditional manner would have made any other choice.

The political situation for the moment is quiet. There have been two good rice harvests in a row. Prices have come down. Landless labourers have work in the new slack season rural works projects. The military government is disinvesting nationalised industries and encouraging foreign investment. Foreign aid has been pouring into the country once again. The majority of the popularion seems unconcerned about the cancellation of parliamentary elections originally scheduled for March of this year. But this situation will not last indefinitely. The Bengali population, long known for its volatile political passions, will not for long remain content with the lack of a political voice. The long-suffering peasantry will not forever remain passive. And most importantly the contradictions of slow and uneven capitalist development remain.

\section{References}

Ahmed, Feroze, 1973, 'The Structural Matrix of the Struggle in Bangladesh', in Gough and Sharma (eds.), Imperialism and Revolution in South Asia, Monthly Review NY
Alavi, H. A., 1972, 'The State in Post-Colonial Societies: Pakistan and Bangladesh', New Left Review, No. 72, July-August

Ayoob, Md. \& Subramanyam, K., 1972, The Liberation War New Delhi

Blackburn, R. (ed.), 1975, Explosion in a Subcontinent, Penguin, Harmondsworth

Cohen, Stephen P., 1971, The Indian Army, Berkeley

Far Eastern Economic Review (FEER), Hong Kong

Gough, K. \& Sharma, H. (eds.), 1973, Imperialism and Revolution in South Asia, Monthly Review, NY

International Institute for Strategic Studies (IISS), 1973-74, 1974-75, 1975-76, 1976-77, The Military Balance, London (Annual)

Jackson, Robert, 1975, South Asian Crisis, IISS, London

Kaldor, Mary, 1976, The Military in Development, World Development, May

Keesing's Contemporary Archives, London

Khan, Maj. Gen. (ret.) Fazal Muqeem, 1973, Pakistan's Crisis in Leadership, Islamabad

Luckham, Robin, 1976, The Military, Militarism and Dependence in the Third World (mimeo)

Maniruzzaman, Talukder, 1973, 'Radical Politics and the Emergence of Bangladesh', in Brass \& Franda (eds.), Radical Politics in South Asia, MIT, Cambridge (Mass.)

1975a, Bangladesh in 1974: Economic Crisis and Political Polarisation, Asian Survey (Berkeley), Vol. XV, No. 2, February

1975b, 'Bangladesh: An Unfinished Revolution?', Journal of Asian Studies, Vol. XXXIV, No. 4, August

1976, 'Bangladesh in 1975: The Fall of the Mujib Regime and its Aftermath', Asian Survey, Vol. XVI, No. 2, February

1977, 'Bangladesh in 1976, Struggle for Survival as an Independent State', Asian Survey, Vol. XVII, No. 2, February

Palit, Maj. Gen. (ret.) D. K., 1972, The Lightning Campaign: The Indo-Pakistan War 1971, Compton Press, Salisbury

Stockholm International Peace Research Institute (SIPRI), 1971-1976 Yearbook on Armament and Disarmament, MIT Press, Cambridge (Mass) (annual)

1974, Arms Trade Registers SIPRI, Stockholm

1975, The Arms Trade with the Third World, Penguin, Harmondsworth

US Arms Control and Disarmament Agency (USACDA), 1976, World Military Expenditures and Arms Trade, 1965-74, Washington, DC 